\title{
Creative thinking and entrepreneurial behavior among K-12 teachers: a predictive study
}

\author{
Roque do Carmo Amorim Neto ${ }^{1}$ \\ Vinícius Picanço Rodrigues ${ }^{2}$ \\ Arnaldo Melendez ${ }^{1}$ \\ ${ }^{1}$ Davenport University, MI, United States of America \\ ${ }^{2}$ Technical University of Denmark, Kgs. Lyngby, Denmark \& Insper, São Paulo, SP, Brazil
}

\begin{abstract}
This study aimed at investigating the influence of creative thinking on teachers' entrepreneurial behavior and the demographic characteristics correlated with teachers' entrepreneurial behavior. Participants were 344 U.S. public school teachers. The mean age was $42.1(\mathrm{SD}=11.5)$ and the mean years of teaching experience was $14.6(\mathrm{SD}=10)$. Female teachers comprised the larger gender group $(n=250,73 \%)$. The results indicated that age and creative thinking were the only variables showing significant unique contributions to entrepreneurial behavior. These findings highlight the importance of creativity for teachers trying to innovate in the classroom. The results also indicate that accumulated experience allows older teachers to better understand how the different layers of the educational system function.
\end{abstract}

Keywords: Creative thinking; Demographics; Entrepreneurial behavior; Teachers.

\section{Pensamento criativo e comportamento empreendedor entre professores da educação básica: um estudo preditivo}

\section{Resumo}

Este estudo teve como objetivo investigar as influências do pensamento criativo e de características demográficas no comportamento empreendedor de professores do ensino básico e médio. Os participantes foram 344 professores de escolas públicas dos Estados Unidos. A idade média foi de 42,1 (desvio padrão=11,5) e a média de anos de experiência foi de 14,6 (desvio padrão=10). Professoras compreendem a maioria da amostra $(n=250,73 \%)$. Os resultados indicaram que a idade e pensamento criativo são as únicas variáveis significativas que contribuem para o comportamento empreendedor em professores. Esses resultados demonstram a importância da criatividade para professores que tentam inovar em sala de aula. Os resultados também mostraram que a experiência acumulada permite aos professores mais velhos entender melhor como as diferentes camadas do sistema educacional funcionam.

Palavras-chave: Pensamento criativo; Variáveis demográficas; Comportamento empreendedor; Professores.

\section{Pensamiento creativo y comportamiento emprendedor entre maestros: un estudio predictivo}

\section{Resumen}

El objetivo de este estudio fue investigar la influencia del pensamiento creativo sobre el comportamiento empresarial de los maestros y las características demográficas correlacionadas con el comportamiento empresarial de los docentes. Los participantes fueron 344 maestros de las escuelas públicas de los Estados Unidos. La media de edad fue de 42,1 (DE=11,5) y la media de años de experiencia docente fue de 14,6 (DE=10). Las mujeres docentes comprendían el grupo de género más grande $(\mathrm{n}=250,73 \%)$. Los resultados indicaron que la edad y el pensamiento creativo eran las únicas variables que mostraban contribuciones únicas significativas al comportamiento empresarial. Estos hallazgos destacan la importancia de la creatividad para los maestros que tratan de innovar en el aula. Los resultados también indican que la experiencia acumulada permite a los maestros mayores comprender mejor cómo funcionan las diferentes capas del sistema educativo.

Palabras clave: Pensamiento creativo; Características demográficas; Comportamiento emprendedor; Maestros. 


\section{Introduction}

According to Adebayo and Kolawole (2013), the word entrepreneurship is derived from the French word "entreprendre," which indicates an act in which the individual attempts, tries, adventures, or undertakes an act of some sort. Pittaway and Freeman (2011) further add that French economist and businessman Jean Baptiste Say developed the term to relate to the change of resources from low to high productivity. Adebayo and Kolawole (2013) also suggest that entrepreneurs exist in any profession. In fact, the definition of entrepreneurship seems to vary according to the field examining it. For example, coming from the business perspective, Rindova, Barry, and Ketchen (2009) define entrepreneurship as the efforts to bring about new economic, social, institutional, and cultural environments through the actions of an individual or group of individuals. Similarly, Shane and Venkataraman (2000) define entrepreneurship as the scholarly examination of how, by whom, and with what effects opportunities to create future goods and services are discovered, evaluated, and exploited.

In the educational field, van Dam, Schipper and Runhaar (2010) define entrepreneurial behavior as "behaviour that involves recognizing opportunities and marshalling the resources to take advantage of, and acting upon these opportunities" (p. 266). In this sense, highly entrepreneurial teachers are more likely to collaborate with colleagues across disciplines and institutions to positively impact not only their classroom but also the larger educational system (Amorim Neto, Rodrigues, Polega, \& Persons, 2019). They are also more likely to explore ways to gather funds and resources and implement technology-based projects to support student learning (van Dam et al., 2010).

With such positive outcomes in mind, researchers have tried to identify competencies and environmental elements that can foster entrepreneurial behavior (Amorim Neto et al., 2019; Amorim Neto, Rodrigues, Stewart, Xiao, \& Snyder, 2018; van Dam et al., 2010). Several factors can influence an individual's entrepreneurial behavior - from competencies to environmental characteristics; a wide range of research has been devoted to further understanding the predictors of the entrepreneurial phenomenon.

Chaudhary and Chaudhary (2017) investigated the influence of demographic factors on determining entrepreneurial inclination, including age and gender. Chaudhary and Chaudhary highlighted the expectation that individuals within the range of 25-30 years are more energetic, and at the same time have enough experience and capacity to start an entrepreneurial venture. Hatak,
Harms, and Fink (2015) also examined how age and job identification affects entrepreneurial intention. Findings indicated that as employees age, they are less inclined to act entrepreneurially, and that the more they identify with their job, the lower their entrepreneurial intention is. Levesque and Minniti (2006) suggested the existence of an age effect that, as individuals grow older, starting a new firm is less desirable than wage labor, which is a tradable income-producing activity with an instant payoff. Kibler, Wainwright, Kautonen, and Blackburn (2015) argued that another reason for the declining rate of enterprising activity for people over age 50 is the likelihood that they may find it difficult to adapt to the dominant enterprise culture, which often praises a youthful image of the entrepreneur.

Regarding gender, a series of studies (e.g., Kelley, Singer, \& Herrington, 2012; Maes, Leroy, \& Sels, 2014; Mueller \& Dato-on, 2013; Zellweger, Sieger, \& Halter, 2011) have reported lower levels of entrepreneurial inclination among women due to perceived genderspecific barriers. Chaudhary and Chaudhary (2017) added that entrepreneurship has been associated with traits like high risk-taking abilities and achievement orientation, and it appears that women cannot see their perceived characteristics in alignment with the traits required for starting an entrepreneurial venture successfully. The same pattern of gender differences, with females reporting lower levels of entrepreneurial behavior, was also found in a recent study with Brazilian teachers (Amorim Neto, Rodrigues, \& Panzer, 2017).

But the exploration of predictors of entrepreneurship has been extended beyond personal characteristics to focus on competencies that can be developed through training. The comprehensive study carried out by van Dam et al. (2010) inquired into six competencies as potential contributors to entrepreneurial behavior among K-12 teachers: (i) entrepreneurial knowledge, (ii) career adaptability, (iii) occupational self-efficacy, (iv) creative thinking, (v) networking skills, and (vi) teamwork skills. The study reported that career adaptability and creative thinking were the only competencies strongly linked to teachers' entrepreneurial behavior. At the same time, the competences of entrepreneurial knowledge, networking, and teamwork were significant but less strongly correlated with entrepreneurial behavior. Lastly, occupational self-efficacy was not significant as a contributor to teachers' entrepreneurial behavior. The authors argued that this might be due to using a broad occupational self-efficacy scale, as opposed to one focused on teachers.

The relationships between the competencies studied by van Dam et al. (2010) and teachers' entre- 
preneurial behavior was further investigated in the work of Amorim Neto et al. (2018) in regards to self-efficacy, and in the work of Amorim Neto et al. (2019) for career adaptability. While Amorim Neto et al. (2018) discovered that occupational self-efficacy is slightly better at predicting teachers' entrepreneurial behavior when compared to specific teacher selfefficacy, the study carried out by Amorim Neto et al. (2019) inquired deeply into how and why teachers adapt their teaching practices in the classroom. While we have tested two of the strongest predictors of entrepreneurial behavior identified by van Dam et al. (2010), creative thinking has not yet been tested as a predictor of entrepreneurial behavior. Therefore, there is still a gap in understanding how creative thinking in particular predicts teachers' entrepreneurial behavior.

\section{Creative Thinking}

Throughout the years of research in this area, many definitions of creative thinking were formulated (Okpara, 2007). For example, Craft (2001) defines creative thinking as the application of knowledge and skills in new ways to achieve a goal. Glass (2004) defines creative thinking as the entire set of cognitive activities used by individuals according to a specific object, problem and condition, or a type of effort toward a particular event and its problem based on the capacity of the individuals. Narrowing the focus on problem solution, Ayob, Hussain, and Majid (2013) view creative thinking as a process of identifying problems, finding possible solutions, making hypotheses, evaluating, and communicating the results.

The first systematic study of creativity has been credited to Galton in 1869 (Jesson, 2012; Zaccaro, 2007). Galton investigated the hereditary determination of creative performance. He emphasized two basic points, which form (or misinform) popular notions of creativity. The first point defined creativity as a unique property of extraordinary individuals, whose decisions may radically change the streams of history. The second point grounds the unique attributes of such individuals in their inherited genetic makeup (Jesson 2012; Zaccaro, 2007). Zaccaro (2007) further states that Galton argued that the personal qualities defining effective creativity were naturally endowed and passed from generation to generation. But these findings were in contradiction to the general public's opinion, and not well-received by other psychologists in the field (Mitchell, n.d.). More recent studies have shown that creative thinking is a skill that can be learned and expressed at various levels in daily life (Burkus, 2013; Daskolia, Dimos, \& Kampylis, 2012).
Creativity research continued to increase, as seen in Guildford's presidential address to the American Psychological Association in 1950, in which he advocated for the scientific inquiry of creativityrelated topics (Kaufman \& Beghetto, 2009). Since then, creativity studies have been applied across a wide range of other disciplines, including business, clinical psychology, developmental studies, technology, and education (Plucker, Beghetto, \& Dow, 2004). This wide interest in creativity can be explained by its link with economic growth. According to Florida (2003), there are many indications that societies with high economic growth also have high levels of creativity. Furthermore, the author adds, the creative thinking process is of great importance to society because many manufacturing companies rely on product development and innovation.

The process of thinking creatively also has a direct influence on educational outcomes. Creative individuals tend to be intrinsically motivated to perform a task, and teachers' training is fundamental to exploring the potentials of creativity within the classroom (Fasko, 2001). Ferrari, Cachia, and Punie (2009) emphasized the need for stimulating students' creative and innovative potential due to (i) the growing body of new media and technologies that enables learning, (ii) the immersion in environments that allow students to learn and understand in different ways, fostering the development of creative approaches and teaching practices, and (iii) creativity as a form of knowledge creation. Ferrari et al. (2009) argue that fostering creative thinking produces positive outcomes in learning, such as enhanced self-learning, improved abilities for "learning to learn," and the development of skills connected to lifelong learning.

Barry and Kanematsu (2008) successfully carried out the "International Program to Promote Creative Thinking in Chemistry and Science" in creative education in the United States and Japan. The program was awarded the National Award (Certificate of Excellence in Public Relations) from the American Chemical Society in 2007. The goal of the program was to promote creative thinking in science and chemistry, and to develop students' problem-solving skills. It was carried out by using innovative teaching techniques and tools, each of them serving as a teaching program component. These components included several teaching approaches: multisensory, science fairs project, reading stories and solving a mystery, space science, and creative engineering design. The results of each approach were very successful. Between $93 \%$ and $100 \%$ of students received satisfactory ratings in the workshops. 
In addition to the educational field, creative thinking has also been explored in the context of entrepreneurship. In evaluating the contribution of creativity to entrepreneurship theory and practice, Fillis and Rentschler (2010) state that creativity can provide the basis for innovation and business growth, as well as generating positive impacts on society. Fillis and Rentscher (2010) add that entrepreneurship occurs in all types and sizes of organizations, from domestic to global corporations. Another piece of evidence comes from a study conducted by Hamidi, Wennberg, and Berglund (2008), with individuals enrolled in graduate entrepreneurship programs. Researchers found that high scores on creativity tests, coupled with entrepreneurial experiences, were positively correlated with entrepreneurial intentions.

While there is growing evidence of the impact of creative thinking on the educational field and the various areas of entrepreneurship, evidence of the predictive power of creative thinking on teachers' entrepreneurial behavior is scarce. This study is designed to help fill this gap.

\section{Current Study}

This study aimed at investigating (1) the influence of creative thinking on teachers' entrepreneurial behavior and (2) the general demographic characteristics correlated with teachers' entrepreneurial behavior. The supporting research questions were: (1) To what extent does creative thinking contribute to teachers' entrepreneurial behavior? (2) Which demographic variables are related to teachers' entrepreneurial behavior?

By addressing these questions, this study contributes to the literature of entrepreneurship in two main streams. First, it furthers the inquiry initiated by van Dam et al. (2010) on the competencies and demographic characteristics that can predict entrepreneurial behavior. Second, it adds empirical evidence to the growing body of knowledge concerning the entrepreneurship phenomenon in the educational field and - more specifically - among teachers.

\section{Method}

\section{Participants and procedures}

To comprise a convenience sample, 391 public school teachers across the United States received an electronic invitation to participate in this study. They were informed of the goal of the study and their right not to participate, as well as to withdraw their participation at any time. They were also reminded that if they participated in the study, their identities would remain anonymous and they could enter a drawing of four US\$ 50 gift cards.

Of the 391, 344 completed the online survey (response rate $=88 \%$ ). The majority of the participants had a graduate degree $(n=219,64 \%)$, taught general education $(n=287,84 \%)$ and taught at high school level $(\mathrm{n}=187,55 \%)$. The mean age was $42.1(\mathrm{SD}=11.5)$ and the mean years teaching experience was 14.6 $(\mathrm{SD}=10)$. Female teachers comprised the larger gender group $(n=250,73 \%)$. The gender distribution of the participants of this study mimics the national teacher population. According to the U.S. Department of Education, National Center for Education Statistics (2016), female teachers comprised $76 \%$ of public school teachers in the United States in 2015.

\section{Measures}

Demographics. Participants indicated their age, gender, discipline and grade level taught, and years of teaching experience.

Entrepreneurial behavior. Teachers' entrepreneurial behavior was assessed by a 17-item instrument developed by Van Dam et al. (2010). Examples of items are "I kept a close eye on new developments in the educational field" and "I usually waited to see how things worked out." Chronbach's alpha was 0.85 .

Creative thinking. To assess creative thinking, we used ten items of the International Personality Item Pool (Goldberg et al., 2006). This scale includes items such as "I have a vivid imagination" and "I love to think up new ways of doing things". Chronbach's alpha was 0.81 .

\section{Analyses}

We used descriptive statistics to calculate frequencies, averages, and correlations. We calculated the Chronbach's alpha to determine the internal consistency reliability of the creative thinking and the entrepreneurial behavior scales. And we conducted a regression analysis to identify the predictors of entrepreneurial behavior. Demographic information and creative thinking were included in the predictive model. For the categorical variables of discipline (general and special education), grade level (K-2, $3-5,6-8$, and 9-12), gender (female and male), and highest degree achieved (undergraduate and graduate degrees), we selected the category with the largest number of participants as baseline and used the others as dummies. The categories used as reference were general education for discipline, 9-12 for grade level, female for gender, and graduate degrees for highest degree achieved. 


\section{Results}

This study aimed at identifying the predictors of entrepreneurial behavior $(\mathrm{M}=3.56, \mathrm{SD}=0.48)$. In addition to the demographic information, creative thinking $(\mathrm{M}=3.91, \mathrm{SD}=0.58)$ was included in the predictive model. Table 1 shows the results of the regression analysis, indicating that age $(\beta=.17, p<.05)$ and creative thinking $(\beta=.51, p<.001)$ were the only variables to show significant unique contributions to entrepreneurial behavior. Analysis also showed that $25 \%$ of the variance on entrepreneurial behavior is accounted for by creative thinking and age.

TABLE 1

Results of the regression analysis with entrepreneurial behavior as dependent variable

\begin{tabular}{lc}
\hline Variable/Group & $\beta$ \\
Age & $.17^{*}$ \\
Creative Thinking & $.51^{* * *}$ \\
Discipline & .06 \\
$\quad$ Special Ed - General Ed & \\
Educational Background & -.02 \\
$\quad$ Undergrad - Graduate degree & \\
Gender & .01 \\
$\quad$ Male - Female & \\
Grade Level & .05 \\
$\quad$ K-2 - 9-12 & .09 \\
$3-5-9-12$ & .01 \\
6-8 - 9-12 & -.1 \\
Teaching Experience & .25 \\
$R^{2}$ adjusted & $13.51^{* * *}$ \\
$F$ & \\
\hline $\mathrm{N}=344$. & \\
$* p<.05 ; * p<.001$. &
\end{tabular}

\section{Discussion}

This study aimed at investigating (i) the influence of creative thinking on teachers' entrepreneurial behavior and (ii) the general demographic characteristics correlated with teachers' entrepreneurial behavior. The results show that creative thinking can moderately predict entrepreneurial behavior among K-12 teachers. In addition, from all the demographic variables evaluated, only age significantly influenced teachers' entrepreneurial behavior. The particularities and implications of these findings were discussed.

As expected, creative thinking is a statistically significant predictor of entrepreneurial behavior among teachers. In line with what was discussed by van Dam et al. (2010), creative thinking is usually a relevant predictor of the entrepreneurs' rise and success. Creative thinking has also been widely associated with the creation of new ideas and abstractions, as well as concrete things. Therefore, a link between creativity and entrepreneurship is expected. Furthermore, higher levels of creative thinking allow individuals to design new ideas and successfully bring them to life in some sort of continuum between pure exploratory ideas (creativity) and concrete outcomes (entrepreneurship). Creative thinking processes also refer to taking unusual perspectives on problems and continually exploring new ways of tackling them (Amabile, 1996; van Dam et al., 2010). Therefore, highly creative teachers are better equipped with the means for identifying and acting upon opportunities through the use of new and unusual connections between problems and potential solutions. Moreover, creative teachers might be more persistent when it comes to tackling problems related to the lack of resources and unexpected learning outcomes in the classroom. Teachers displaying high levels of creative thinking might also be more inclined to engage in entrepreneurial activities, due to their increased ability to apply knowledge and skills in new ways to achieve a specific goal (Craft, 2001). In other words, this might mean that more creative teachers tend to see opportunities where and when no one else does.

In regards to age as a predictor of entrepreneurial behavior among teachers, the result resonates with what has been found in the literature of educational entrepreneurship (Amorim Neto et al., 2018). It is often understood that older individuals display a higher inclination towards entrepreneurship due to enhanced means and opportunities for innovating within the boundaries of the classroom (Kautonen, Hatak, Kibler, \& Wainwright, 2015; Weber \& Schaper, 2004). In general, older teachers are more experienced in a multitude of subjects and characteristics, as age has also been vastly used as a proxy for professional experience. The accumulated experience allows teachers to better understand the functioning of the different layers of the educational system, from their own school's rules and culture to the broader educational context. Older teachers might also have had higher exposure to topics pertaining to the realm of entrepreneurship, either through their own academic background or via interactions with other institutions and individuals.

Entrepreneurial behavior encompasses activities that are often uncertain and loosely defined in terms of real returns. Even though there is an understanding that older individuals tend to invest much in such activities (Fung, Lai, \& Ng, 2001; Hatak et al., 2015), there is still 
reason to believe that more experienced teachers will display higher entrepreneurial behavior. This might be due to the fact that teachers operate in a working environment capable of providing them with "safety nets" and more structured support toward risking and engaging in entrepreneurial tasks (Amorim Neto et al., 2019; Amorim Neto et al., 2018). With that in mind - and linking to the concept of creative thinking - it is possible to argue that entrepreneurial behavior might be a clear representation of how teachers make strategic use of a wider repertoire of experiences toward identifying and acting upon innovation opportunities in a creative way.

Some of the study's limitations are then presented. First, the research setup is based on a quantitative approach and lacks the deeper insights that the qualitative approach could add. Second, several aspects of the organizational climate in schools as put forth and explored by van Dam et al. (2010) - were not accounted for in our quantitative model, which focused solely on demographic characteristics and competencies. Third, the research was exclusively conducted with U.S. teachers, which might limit the generalizability of the findings across multiple cultures and countries.

With a view to addressing the aforementioned limitations and therefore developing the field further, future research streams point toward (i) investigating qualitative aspects of teachers' creative thinking processes, based for example on in-depth interviews and/or open qualitative questions, such as how teachers perceived themselves as acting creatively; (ii) directly considering aspects of organizational climate raised in the literature as well as elements of culture with the objective of gauging how such cultural aspects might influence creative thinking processes among teachers, and (iii) comparing findings across multiple cultural and national contexts to identify cultural specificities on creative thinking and entrepreneurial behavior.

\section{References}

Adebayo, O. \& Kolawole, J. A. (2013). The historical background of entrepreneurial development in Nigeria: Its gains, shortcomings and needful. Journal of Emerging Trends in Economics and Management Sciences, 4(5), 493-500.

Amabile, T. M. (1996). Creativity in context. Boulder, CO: Westview Press.

Amorim Neto, R. C., Rodrigues, V. P., \& Panzer, S. (2017). Exploring the relationship between entrepreneurial behavior and teachers' job satisfaction. Teaching and Teacher Education, 63, 254-262. http://dx.doi.org/10.1016/j. tate.2017.01.001

Amorim Neto, R. C., Rodrigues, V. P., Polega, M., \& Persons, M. (2019). Career adaptability and entrepreneurial behaviour in the K-12 classroom. Teachers and Teaching, 25(1), 90-109. https://doi.org/10.1080/13540602.2018.15 26783

Amorim Neto, R. C., Rodrigues, V. P., Stewart, D., Xiao, A., \& Snyder, J. (2018). The influence of self-efficacy on entrepreneurial behavior among K-12 teachers. Teaching and Teacher Education, 72, 44-53. https://doi.org/10.1016/j. tate.2018.02.012

Ayob, A., Hussain, A., \& Majid, R. A. (2013). A review of research on creative teachers in higher education. International Education Studies, 6(6), 8-14. https://doi.org/10.5539/ies.v6n6p8

Barry, D. M. \& Kanematsu, H. (2008). International program promotes creative thinking in science. The Education Resources Information Center (ERIC). Retrieved from: http://files.eric.ed.gov/fulltext/ED500317.pdf

Burkus, D. (2013). The myths of creativity: The truth about how innovative companies and people generate great ideas. San Francisco, CA: Jossey-Bass.

Chaudhary, R. \& Chaudhary, R. (2017). Demographic factors, personality and entrepreneurial inclination: A study among Indian university students. Education + Training, 59(2), 171-187. https://doi.org/10.1108/ET-02-2016-0024

Craft, A. (2001). An analysis of research and literature on creativity in education. Report prepared for the Qualifications and Curriculum Authority. Retrieved from: ncys.ksu.edu.sa

Daskolia, M., Dimos, A., \& Kampylis, P. (2012). Secondary teachers' conceptions of creative thinking within the context of environmental education. International Journal of Environmental and Science Education, 7, 269-290.

Fasko, D. (2001). Education and creativity. Creativity Research Journal, 13(3-4), 317-327. https://doi.org/10.1207/ S15326934CRJ1334_09

Ferrari, A., Cachia, R., \& Punie, Y. (2009). Innovation and creativity in education and training in the EU member states: Fostering creative learning and supporting innovative teaching. JRC Technical Note, 52374.

Fillis, I. \& Rentschler, R. (2010). The role of creativity in entrepreneurship. Journal of Enterprising Culture, 18(1), 49-81. https://doi.org/10.1142/S0218495810000501

Florida, R. (2003). Cities and the creative class. City \& Community, 2(1), 3-19. https://doi.org/10.1111/1540-6040.00034

Fung, H. H., Lai, P., \& Ng, R. (2001). Age differences in social preferences among Taiwanese and Mainland Chinese: The role of perceived time. Psychology and Aging, 16(2), 351-356. https://doi.org/10.1037//0882-7974.16.2.351 
Glass, T. (2004). What gift? The reality of the student who is gifted and talented in public school classrooms. Gifted Child Today, 2(4), 25-29. https://doi.org/10.4219/gct-2004-152

Goldberg, L. R., Johnson, J. A., Eber, H. W., Hogan, R., Ashton, M. C., Cloninger, C. R., \& Gough, H. G. (2006). The international personality item pool and the future of the public-domain personality measures. Journal of Research in Personality, 40, 84-96. https://doi.org/10.1016/j/jrp.2005.08.007

Hamidi, D. Y., Wennberg, K., \& Berglund, H. (2008). Creativity in entrepreneurship education. Journal of Small Business and Enterprise Development, 15(2), 304-320. https://doi.org/10.1108/14626000810871691

Hatak, I., Harms, R., \& Fink, M. (2015). Age, job identification, and entrepreneurial intention. Journal of Managerial Psychology, 30(1), 38-53. https://doi.org/10.1108/JMP-07-2014-0213

Jesson, J. (2012). Developing creativity in the primary school. Berkshire, UK: McGraw-Hill Education.

Kaufman, J. C. \& Beghetto, R. A. (2009). Beyond big and little: The four c model of creativity. Review of General Psychology, 13, 1-12. https://doi.org/10.1037/a0013688

Kautonen, T., Hatak, I., Kibler, E., \& Wainwright, T. (2015). Emergence of entrepreneurial behaviour: The role of age-based self-image. Journal of Economic Psychology, 50, 41-51. https://doi.org/10.1016/j.joep.2015.07.004

Kelley, D. J., Singer, S., \& Herrington, M. (2012). The global entrepreneurship monitor. 2011 global report. Global Entrepreneurship Research Association. Available from: www.gemconsortium.com

Kibler, E., Wainwright, T., Kautonen, T., \& Blackburn, R. (2015). Can social exclusion against "older entrepreneurs" be managed? Journal of Small Business Management, 53(S1), 193-208. https://doi.org/10.1111/jsbm.12194

Levesque, M. \& Minniti, M. (2006). The effect of aging on entrepreneurial behavior. Journal of Business Venturing, 21(2), 177-194. https://doi.org/10.1016/j.jbusvent.2005.04.003

Maes, J., Leroy, H., \& Sels, L. (2014). Gender differences in entrepreneurial intentions: A TPB multi-group analysis at factor and indicator level. European Management Journal, 32(5), 784-794. https://doi.org/10.1016/j.emj.2014.01.001

Mitchell, R. N. (n.d.). Francis Galton's Hereditary Genius, 1869 \& 1892. Retrieved from: http://www.branchcollective. org/?ps_articles=rebecca-n-mitchell-francis-galtons-hereditary-genius-1869-1892

Mueller, S. L. \& Dato-on, M. C. (2013). A cross cultural study of gender-role orientation and entrepreneurial self-efficacy. International Entrepreneurship and Management Journal, 9(1), 1-20. https://doi.org/10.1007/s11365-011-0187-y

Okapara, F. O. (2007). The value of creativity and innovation in entrepreneurship. Journal of Asia Entrepreneurship and Sustainability, 3(2), 81-131.

Pittaway, L. \& Freeman, W. A., (2011). The evolution of entrepreneurship theory. Working Paper, 1, 1-33.

Plucker, J. A., Beghetto, R. A., \& Dow, G. T. (2004). Why isn't creativity more important to educational psychologists? Potentials, pitfalls, and future directions in creativity research. Educational Psychologist, 39(2), 83-96. https://doi. org/10.1207/s15326985ep3902_1

Rindova, V., Barry, D., \& Ketchen, D. J. (2009). Entrepreneuring as emancipation. Academy of Management Review, 34(3), 477-491. https://doi.org/10.5465/amr.2009.40632647

Shane, S. \& Venkataraman, S. (2000). The promise of entrepreneurship as a field of research. Academy of Management Review, 25(1), 217-226. https://doi.org/10.5465/amr.2000.2791611

U.S. Department of Education, National Center for Education Statistics. (2016). Digest of Education Statistics, 2015. Retrieved from: https://nces.ed.gov

van Dam, K., Schipper, M., \& Runhaar, P. (2010). Developing a competency-based framework for teachers' entrepreneurial behaviour. Teaching and Teacher Education, 26(4), 965-971. https://doi.org/10.1016/j.tate.2009.10.038

Weber, P. \& Schaper, M. (2004). Understanding the grey entrepreneur. Journal of Enterprising Culture, 12(2), 147-164. https://doi.org/10.1142/S0218495804000087

Zaccaro, S. J. (2007). Trait-based perspectives of leadership. American Psychologist, 62, 6-16. https://doi. org/10.1037/0003-066X.62.1.6

Zellweger, T., Sieger, P., \& Halter, F. (2011). Should I stay or should I go? Career choice intentions of students with family business background. Journal of Business Venturing, 26(5), 521-536. https://doi.org/10.1016/j.jbusvent. 2010.04 .001

Dados dos autores:

Roque do Carmo Amorim Neto - Doutor, Davenport University.

Vinícius Picanço Rodrigues - Doutor, Technical University of Denmark \& Insper.

Arnaldo Melendez - Mestre, Davenport University.

Endereço para correspondência:

Roque do Carmo Amorim Neto

College of Urban Education, Davenport University

6191 Kraft Ave. Grand Rapids, MI 49512, USA

<roque.neto@davenport.edu>

Recebido em: 21.09.2017

Aceito em: 16.10.2018 